OPEN ACCESS

Citation: Federico Martinelli, Anna Perrone, Abhaya M. Dandekar (2021) Development of a protocol for genetic transformation of Malus spp. Caryologia 74(3): 9-19. doi: 10.36253/caryologia-1248

Received: March 11, 2021

Accepted: August 10, 2021

Published: December 21, 2021

Copyright: (C 2021 Federico Martinelli, Anna Perrone, Abhaya M. Dandekar. This is an open access, peer-reviewed article published by Firenze University Press (http://www.fupress.com/caryologia) and distributed under the terms of the Creative Commons Attribution License, which permits unrestricted use, distribution, and reproduction in any medium, provided the original author and source are credited.

Data Availability Statement: All relevant data are within the paper and its Supporting Information files.

Competing Interests: The Author(s) declare(s) no conflict of interest.

\section{Development of a protocol for genetic transformation of Malus spp}

\author{
Federico Martinelli $^{1, *}$, Anna Perrone ${ }^{2}$, Abhaya M. Dandekar ${ }^{3}$ \\ ${ }^{1}$ Department of Biology, University of Florence, Sesto Fiorentino, Florence, 50019, Italy \\ ${ }^{2}$ Department of Biological, Chemical and Pharmaceutical Sciences and Technologies \\ (STEBICEF), University of Palermo, Viale delle Scienze, Palermo, 90128, Italy \\ ${ }^{3}$ Department of Plant Sciences, University of California, One Shields Avenue, Mail Stop 4, \\ Davis, CA 5616, USA \\ *Corresponding author. E-mail: federico.martinelli@unifi.it
}

\begin{abstract}
A protocol to produce transgenic shoots of Malus X domestica cv Greensleaves was optimized using two gene constructs previously used to create parthenocarpic tomato, Ino-IaaM and DefH9-IaaM. The aim was to obtain sufficient $\mathrm{n}^{\circ}$ of transgenic shoots for in vitro multiplication, transfer to soil, grafting and testing for parthenocarpy in the next years. We investigated the effects of two modifications of a previous published protocol: 1) co-transformation with an Agrobacterium containing "VIP" genes in the gene construct and 2) two different hormones or hormone combinations. More shoot regeneration was obtained with a combination of three hormones (BA:NAA:TDZ) during co-cultivation instead of IBA and no co-transformation was performed using the VIP gene. For the DefH9-IaaM transgene, 21.04\% regeneration was achieved for this treatment instead of $8.95 \%$ achieved with "IBA treatment" and $4.42 \%$ with the Agrobacterium co-transformation treatment. More shoot regeneration occurred with the combination of three hormones (BA:NAA:TDZ) instead of with only IBA and no co-transformation was performed using VIP gene. Experiments using Ino-IaaM confirmed the results shown for the DefH9-IaaM transgene. The regenerated shoots were multiplied in selective media containing kanamycin and roots were obtained.
\end{abstract}

Keywords: apple, Greensleaves, genetic transformation, Malus, organogenesis, TDZ

\title{
INTRODUCTION
}

Traditional genetic improvement in woody fruit species used selection and breeding, resulting in relatively few genotypes and a restricted germplasm base. This genetic uniformity has increased vulnerability of woody crops to insect pests and pathogens and caused excessive use of chemicals (Norelli et al. 1994) Genetic transformation provides an alternate approach through introduction of genes encoding desirable traits (Jia et al. 2019), bypassing the long periods required for genetic crosses and selection. Once a useful transgenic plant is isolated (assuming the transgene expression is stable), vegetative propagation allows rapid production of the desired trans- 
genic line. Genetic improvement of an elite cultivar can occur because there is no sexual reproduction. Since production of most fruit tree species is based on a few cultivars, the impact of genetically transforming them is important.The characterization of induced overll metabolism changes using omic tools has been previously done (Tosetti et al. 2010; Rizzini et al. 2010).

The most widely produced commercial transgenic tree crop is papaya (Carica papaya L.) resistant to PRSV (Papaya Ringspot Virus), while transgenic apple is not yet on the market. This is partially due to the absence of efficient regeneration protocols for important commercial cultivars of Malus X domestica. Protocols developed for one cultivar are often not suitable for other cultivars of the same species. In some cases, genetic transformation has been obtained only from seedling material (Mante et al. 1991). The time required for transformation and evaluation of phenotype is generally much longer for tree crops (three to 20 years) than for herbaceous species. Space requirements can be large and evaluation of transgenic tree crops, expensive and time-consuming. However, conventional breeding for new cultivars has the same requirements. Among molecular genetic approaches, genetic transformation is probably the most important tool to increase the speed of cultivar creation, because it avoids some disadvantages of conventional breeding, like loss of desirable characteristic in the offspring. In addition, the small number of cultivars produced for each woody species increases the impact of genetic improvement of one of them. For example, over 50\% of world and United States apple production is based on Red Delicious, Golden Delicious, Granny Smith, Gala and Fuji. An improvement of one of these cultivars can have a significant impact on total production.

Methods for plant transformation fall into three main groups:1) biological vectors (virus- or Agrobacterium-mediated transformation; 2) direct DNA transfer (chemical-, electrical- or microlaser-induced permeability of protoplasts or cells; and 3) non-biological vector systems (microprojectiles, microinjection or liposome fusion). The availability of an efficient protocol for regeneration is an important step for recovery of transgenic plants. There are efficient regeneration systems for many herbaceous species (tomato, Arabidopsis, tobacco). However, systems for many woody fruit crops are either not available or suitable only for juvenile material of zygotic origin, which makes them useless for transforming elite cultivars. Dandekar (1992) considered two important conditions for regenerating transgenic plants:1) the regenerating cells must be accessible to Agrobacterium and 2) the regenerated plants must originate from single cells.
Direct adventitious regeneration is preferred to intermediate proliferation of callus because callus can be a source of somaclonal variation, requiring extensive field tests to ensure that regenerated plants are true to type. Also, a pluricellular origin for regenerated plants can produce chimeric plants with variable expression. Genetic transformation of single cells or protoplasts can overcome this situation (Oliveira et al. 1994; Hidaka and Omura, 1993).

Previous work on genetic transformation of apple has focused on genes to improve two kinds of traits: 1) disease resistance against viruses, bacteria, insects and fungi and 2) modification of agronomic phenotypic features, such as columnar growth, rooting ability, freezing tolerance or toxin resistance. Plant resistance to a pathogen is often caused by a hypersensitive response, involving elicitor recognition that activates a cascade of host genes and eventually leads to a generalized response known as systemic acquired resistance (SAR). Previous studies attempted to confer disease resistance by introducing specific resistance genes rather than by activating plural defence mechanisms (Schuerman and Dandekar, 1993).

Most research has focused on virus-induced disease. Some used genes encoding viral coat proteins to increase tolerance to specific viruses such as PRSV (Papaya Ringspot Virus) in papaya (Fitch et al. 1993) and CTV (Citrus Tristeza Virus) in Citrus (Ghorbel et al. 2001). In apricot, the regenerated plants were of zygotic origin and resistance has not yet be recovered from transformed commercial cultivars. Resistance to insects, bacteria and fungi has been developed in Actinidia deliciosa against Botrytis cinerea (Nakamura et al. 1999) and in walnut against Cydia pomonella (Dandekar et al. 1998). A Japanese persimmon cultivar was transformed with the CryIA (c) from Bacillus thuringiensis and biossays with two different lepidopteran pests showed significative resistance to these pathogens. Pear, like apple, is severally affected by fire blight (Erwinia amylovora) and pear cultivars with increased resistance were recovered that expressed D5C1 (Puterka et al. 2002).

The Rol A, B or C genes were used to improve rooting in kiwifruit (Rugini et al. 1991) and in apple rootstocks such as M26 (Welander et al. 1998). In Citrus, the juvenile phase was shortened and precocious flowering was promoted using floral genes such as LEAFY (LFY) and APETALA1 (AP1) from Arabidopsis (Pena et al. 2001). Progeny of the transgenic LFY and AP1 trees had a generation time of one year from seed to seed, but only the AP1 trees had fully normal development. In peach, greater branching and shorter internodes were obtained using strains of Agrobacterium with a silenced auxin 
synthesis gene and intact ipt gene for cytokinin synthesis (Smigocki and Hammerschlag, 1991).

Among tree fruits, apple is used frequently for transgenic research because optimized transformation protocols exist for the elite cultivars Greesleaves (James et al. 1993) and Delicious (Sriskandarjah et al. 1994). Recently, transgenic apple trees with reduced scab susceptibility were obtained by introducing a gene for puroindoline-b from wheat, effective against new races of scab that are resistant to the $V f$ gene (Faize et al. 2004).

Other researchers transformed apple using genes from the biocontrol fungus Trichoderma atroviride encoding the antifungal proteins endochitinase or exochitinase (N-acetyl-beta-D-hexosaminidase) driven by a modified CaMV35S promoter (Bolar et al. 2001). Exochitinase was less effective than endochitinase and the enzymes acted synergistically to reduce disease. The level of expression of endochitinase correlated negatively with apple tree growth, while exochitinase had no consistent effect on growth. Transgenic lines, especially one expressing low levels of endochitinase activity and moderate levels of exochitinase activity, were selected for high resistance in growth chamber trials and negligible reduction in vigor (Bolar et al. 2000, 2001).

Other researchers used T4 lysozyme, attacin or cecropin MB39 genes to enhance resistance of transgenic "Royal Gala" apple trees against Erwinia amylovora (Liu et al. 2001). Transgenic trees were evaluated for fire blight resistance, delayed fruit softening and scab resistance (Bolar et al. 2000). Apple fruit shelf life was improved by altering ethylene biosynthesis using sense or antisense cDNA encoding ACC-synthase and ACC-oxidase (Dandekar et al. 2004). Ethylene biosynthesis was also down-regulated in Gala apple using a SAM-k gene encoding a S-adenosylmethionine hydrolase (SAMase). Resistance to codling moth was obtained using a chemical version of the Bacillus thuringiensis cryAC gene (Dandekar et al. date).

Another important objective of genetic improvement in apple is regulation of tree growth. Apple growth has been modified using RolA genes isolated from Agrobacterium rhizogenes. Apple rootstock M26 transformed with RolA had reduced internode length, dry matter and leaf area. When the scion Gravestein was grafted onto transformed M26, the scion showed reduced stem and internode length without altered leaf area and relative growth rate (Zhu and Welander, 1999). RolB promotes rooting through increased auxin sensitivity (Delbarre et al. 1994). This gene has been successfully inserted into the apple rootstocks M26 (Welander et al. 1998) and Jork9 (Sedira et al. 2001).
Self-incompatibilty restricts fertilization and fruit set in apple and makes pollinator plants necessary for orchard productivity. Transgenic plants created with deleted pisitil S-RNase proteins, which are responsible for self-incompatibility, produced normal fruit and seeds after selfing (Broothaerts et al. 2004).

This work tested different hormone combinations and co-cultivation with different Agrobacterium harboring VIP genes to improve regeneration of transgenic apple shoots. We used two plasmid constructs containing ovule-specific promoters to induce expression of the IaaM gene, which is involved in auxin biosynthesis. The resulting trees will be evaluated for the presence of seeds, since these gene constructs were used successfully to cause parthenocarpy in tomato cv Micro-Tom.

\section{MATERIALS AND METHODS}

Binary vectors, plant materials and treatments - Two binary vectors were used to transform apple cv Greensleaves. The first, pDU04100, contained the IaaM gene (involved in auxin biosynthesis) in a sense orientation, under the control of ovule-specific promoter "Ino," isolated from Arabidopsis ovary integument (Meister et al. 2004). The second, pDU04160, contained IaaM in a sense orientation under the control of another ovulespecific promoter, DefH9, isolated from Anthirrium majus ovary (Martinelli et al. 2019).

Apple cv Greensleaves was cultured in vitro in shoot multiplication medium (A17) under controlled temperature $\left(18\right.$ to $25^{\circ} \mathrm{C}$ ) and 16 -hour photoperiod (fluorescent light) with no bacterial or fungi contamination. The plants were subcultured and separated every? months.

The effects of several treatments on transformation efficiency were studied:

- BA:NAA:TDZ (5:1:1, (mg/L))

- IBA (3 mg/L)

- cotransformation with Agrobacterium containing the VIP1 gene construct as described (Escobar and Dandekar 2003, Raman et al. 2019).

The A17 shoot multiplication medium consisted of $30 \mathrm{~g} / \mathrm{L}$ sorbitol, $431 \mathrm{~g} / \mathrm{L}$ MS salts (macro- and micronutrients), $100 \mathrm{mg} / \mathrm{L}$ myo-inositol, $1 \mathrm{~mL} / \mathrm{L}$ 1000x MS vitamin stock, $1 \mathrm{~mL} / \mathrm{L}$ of $1 \mathrm{mg} / \mathrm{mL}$ IBA, $1 \mathrm{~mL} / \mathrm{L}$ of $1 \mathrm{mg} / \mathrm{mL}$ BA and $8 \mathrm{~g}$ Bactoagar, pH 5.8.

\section{Rooting of shoots}

The apple cv Greensleaves shoots used for genetic transformation were rooted using a two-phase method: root induction and root emergence. Shoots were trans- 

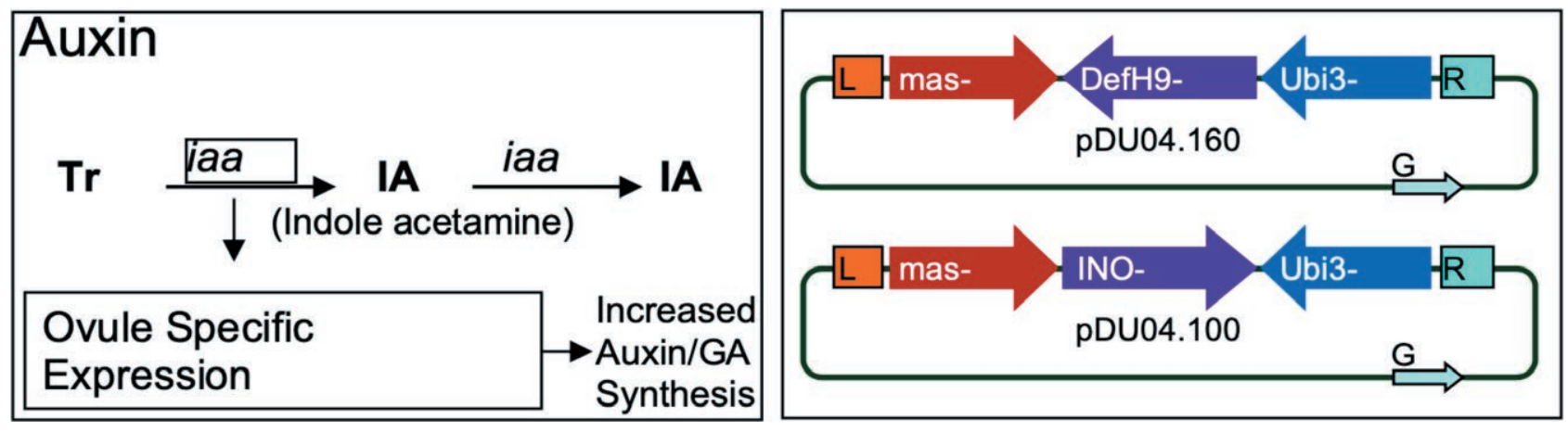

Figure 1. Objective and scheme of the two ovary-specific gene constructs used for genetic transformation of 'Micro-Tom' tomato. Role of gene IaaM in auxin biosynthesis. Also the mechanism to induce parthenocarpy is described briefly.

ferred from A17 medium to RI medium and placed under a 16-hour photoperiod for two to five days (fluorescent light). Next the shoots were transferred to RE medium without cutting off the base and placed under a 16-hour photoperiod (fluorescent light) for four to five weeks until roots emerged and leaves were fully expanded.

Root induction media (RI) was identical to A17 medium, except the BA was omitted. RE medium omitted both BA and IBA.

Agrobacterium preparation - Agrobacterium from frozen stock was inoculated into YEP medium containing $50 \mathrm{mg} / \mathrm{mL}$ Rifampicin, $50 \mathrm{mg} / \mathrm{mL}$ kanamycin sulfate and $20 \mathrm{mg} / \mathrm{mL}$ gentamicin sulfate and incubated overnight at $28^{\circ} \mathrm{C}$. The next day, five $\mathrm{mL}$ YEP medium was inoculated with bacteria from the plate and incubated with shaking at room temperature for two to three hours. Afterward, $10 \mu \mathrm{L}$ Tetracycline were added to five mL YEP medium, swirled, combined with agro-YEP suspension and incubated overnight at room temperature with shaking. The $\mathrm{OD}$ at $\mathrm{A}_{420}$ was determined using 100 $\mu \mathrm{L}$ bacterial suspension from the overnight growth and $900 \mu \mathrm{L}$ YEP. The bacterial cells were centrifuged at 5000 $\mathrm{g}$ for $15 \mathrm{~min}$ at room temperature, resuspended in IM medium to $\mathrm{OD}_{420}=0.5$ and incubated at room temperature with shaking for five hrs.

Agrobacterium growth medium (YEP) consisted of 5 $\mathrm{g} / \mathrm{L}$ Bacto yeast extract, $10 \mathrm{~g} / \mathrm{L}$

Bacto peptone and $10 \mathrm{~g} / \mathrm{L} \mathrm{NaCl}, \mathrm{pH}$ 7.2. Virulence induction medium (IM) consisted of $431 \mathrm{~g} / \mathrm{L}$ MS salts, 1 $\mathrm{ml} / \mathrm{L} 1000 \times \mathrm{MS}$ vitamins, $2 \%$ sucrose, $100 \mathrm{mg} / \mathrm{L}$ myo-inositol, $1 \mathrm{mM}$ proline and $100 \mu \mathrm{M}$ acetosyringone, $\mathrm{pH}$ 5.2.

\section{Genetic transformation protocol}

Leaf discs were cut from leaves of shoots grown in RE media for four to five weeks and placed immediately in Petri dishes containing co-cultivation medium solu- tion with no hormone. The leaf discs were incubated with Agrobacterium suspension for 10 to 20 minutes, blotted onto sterile Whatman filter paper to remove excess bacteria, then transferred to co-cultivation medium supplemented with $200 \mu \mathrm{M}$ acetosyringone and 1 $\mathrm{mM}$ proline (24 discs per plate). Plates were incubated in the dark at $21^{\circ} \mathrm{C}$ for three days and transferred to regeneration medium. Plates were checked weekly for regenerants and the explants were transferred to fresh medium monthly. As soon as they appeared, regenerated shoots were transferred to A17 medium supplemented with 200 $\mu \mathrm{g} / \mathrm{mL}$ cefotaxime and $100 \mu \mathrm{g} / \mathrm{mL}$ kanamycin and incubated under 16 hours photoperiod at room temperature. The regenerated shoots were divided grown separately in single tubes $(20 \mathrm{~mL})$ in fresh selective A17 until sufficient material was produced for biochemical and molecular analyses. The first co-cultivation medium (CC) was composed of $30 \mathrm{~g} / \mathrm{L}$ sorbitol, $431 \mathrm{~g} / \mathrm{L}$ MS salts (macroand micro-elements), $100 \mathrm{mg} / \mathrm{L}$ myo-inositol, $1 \mathrm{~mL} 1000$ x MS vitamin, $3 \mathrm{~mL} / \mathrm{L} 1 \mathrm{mg} / \mathrm{mL}$ IBA, and $3 \mathrm{~g} / \mathrm{L}$ Gelrite, $\mathrm{pH}$ 5.8. The second co-cultivation medium (CC) was the same, except that the hormones were $5 \mathrm{~mL} / \mathrm{L} 1 \mathrm{mg} /$ $\mathrm{mL} \mathrm{BA}, 1 \mathrm{~mL} / \mathrm{L} 1 \mathrm{mg} / \mathrm{mL} \mathrm{NAA}$ and $1 \mathrm{mg} / \mathrm{mL}$ TDZ. In regeneration medium (RG) the hormone were $5 \mathrm{~mL} / \mathrm{L} 1$ $\mathrm{mg} / \mathrm{mL} \mathrm{BA}, 1 \mathrm{~mL} / \mathrm{L} 1 \mathrm{mg} / \mathrm{mL}$ NAA, $1 \mathrm{~mL} / \mathrm{L} 1 \mathrm{mg} / \mathrm{mL}$ TDZ, $200 \mu \mathrm{g} / \mathrm{ml}$ cefotaxime and $100 \mu \mathrm{g} / \mathrm{mL}$ kanamycin.

\section{Histochemical MUG assay}

Fifty to $100 \mathrm{mg}$ tissue was ground in $100 \mu \mathrm{L}$ extraction buffer in a microcentrifuge tube using a plastic pellet pestle and centrifuged five to $10 \mathrm{~min}$ at $14000 \mathrm{rpm}$ at $4{ }^{\circ} \mathrm{C}$ at room temperature. Fifty $\mu \mathrm{L}$ supernatant was transferred to microcentrifuge tubes containing 450 $\mu \mathrm{L}$ of extraction buffer. Two hundred $\mu \mathrm{L} 4 \mathrm{mM}$ MUG were added, mixed and immediately added to $800 \mu \mathrm{L}$ $.02 \mathrm{M} \mathrm{Na}_{2} \mathrm{CO}_{3}$ (Time 0). Time 0 and remaining sam- 
ples were incubated at $37^{\circ} \mathrm{C}$ for $30 \mathrm{~min}$. Afterward, $200 \mu \mathrm{L}$ of the remaining supernatant was added to 800 $\mu \mathrm{L} .02 \mathrm{M} \mathrm{Na}_{2} \mathrm{CO}_{3}$ and mixed (Time 30). Samples were analyzed under ultraviolet light and the fluorescence of Times 30 and 0 were compared to a control with a fluorometer. Dilutions were made to read fluorescence using .02 $\mathrm{M} \mathrm{Na}_{2} \mathrm{CO}_{3}$. The extraction buffer consisted of $50 \mathrm{mM} \mathrm{NaPO}_{4}, \mathrm{pH} 7 ; 10 \mathrm{mM}$ EDTA, $\mathrm{pH} \mathrm{8;01 \%}$ Triton X-100; .01\% sodium luryl sarcosine; $7 \mu \mathrm{L} / 10 \mathrm{~mL}$ 2- $\beta$-mercaptoethanol; .02 $\mathrm{M} \mathrm{Na}_{2} \mathrm{CO}_{3}$ and $4 \mathrm{mM} \mathrm{MUG}$ (4-methylumbellifery glucoronide).

\section{Rooting and soil transfer of transgenic shoots}

The same procedure described previously to generate shoots used for genetic transformation was also used to root transgenic shoots, although RI and RE media were supplemented with $200 \mu \mathrm{g} / \mathrm{mL}$ cefotaxime and $100 \mu \mathrm{g} /$ $\mathrm{mL}$ kanamycin. Transgenic shoots produced expanded roots and were acclimated.

\section{Statistical analysis}

For each treatment, 20 petri dishes containing 12 explants were used. Three parameters were calculated for each petri dish: 1) the percentage of regeneration (explants forming on at least one shoot/total explants used), 2) the $n^{\circ}$ of regenerated shoots/total explants used, 3) the $n^{\circ}$ of groups of shoots/ total explants used. Means were calculated for each treatment and SPSS statistical software was used to analyse the data with ANOVA univariate and Duncan t-test $(\mathrm{P}=005)$.

\section{RESULTS}

Different hormone combinations were used to improve the genetic transformation protocol, using two constructs containing the IaaM gene driven by DefH9 or Ino, two ovule-specific promoters previously used to transform tomato. Different in vitro plant culture factors were studied for each construct. Two different hormone combinations were used during co-cultivation with the DefH9-IaaM construct. The first was the same combination of hormones used for regeneration (BA:NAA:TDZ at 5,1 and $1 \mathrm{mg} / \mathrm{L}$, respectively). The second was $3 \mathrm{mg} / \mathrm{L}$ IBA to induce callus formation before regeneration.

The effect of co-transformation with two Agrobacterium strains was tested: 1 ) with a construct containing a "VIP1" gene, and 2) with Agrobacterium containing the Ino-IaaM construct. The VIP1 gene increases the
Table 1. Transformation of "Greensleaves" apple using construct DefH9-IaaM. The construct, date and number assigned and a description of the experiments are included. Percentage of regeneration and number of single or grouped shoots regenerated were determined. The letters on the side of the numbers in the same column indicate significative differences calculated using the Duncan test $(\mathrm{P}=005)$.

\begin{tabular}{lccc}
\hline Treatment & \% regeneration & No of shoots & $\begin{array}{c}\text { No of group of } \\
\text { shoots }\end{array}$ \\
\hline Control & $21.04 \mathrm{~b}$ & $1.52 \mathrm{~b}$ & $0.72 \mathrm{~b}$ \\
IBA & $8.95 \mathrm{a}$ & $0.78 \mathrm{a}$ & $0.04 \mathrm{a}$ \\
VIP & $4.42 \mathrm{a}$ & $0.47 \mathrm{a}$ & $0 \mathrm{a}$ \\
\hline
\end{tabular}

number of transformed cells and also their regeneration capacity. Co-cultivation was also studied in two experiments using the construct Ino-IaaM. For all transformation experiments, the regeneration percentage and $n^{\circ}$ single shoots regenerated were measured to determine transformation efficiency. The number of shoot groups were also counted, although it was unclear whether such groups derived from one or several transformation events. Generally, each group formed two to six shoots, of which only one was maintained in culture for confirmation of transformation.

IBA in co-cultivation or co-transformation produced fewer regenerants, a lower percentage of regeneration, and fewer shoots (single or groups) than BA-NAATDZ treatment (Table 1, Figures 2 and 3). Leaf discs transformed with Ino-IaaM showed similar results: more

A)

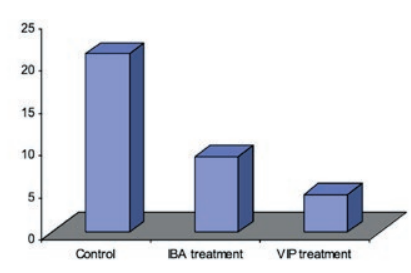

B)

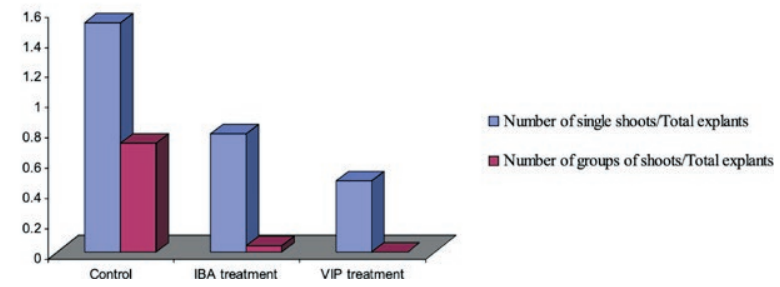

Figure 2. A) Genetic transformation of 'Greensleaves' apple with the DefH9-IaaM gene construct. Percentage of regeneration (explants forming at least one shoot/total explants) for each treatment. B). Genetic transformation of 'Greensleaves' apple with the DefH9-IaaM gene construct. Number of shoots/total explants and number of group of shoots/total explants are indicated for each treatment. 

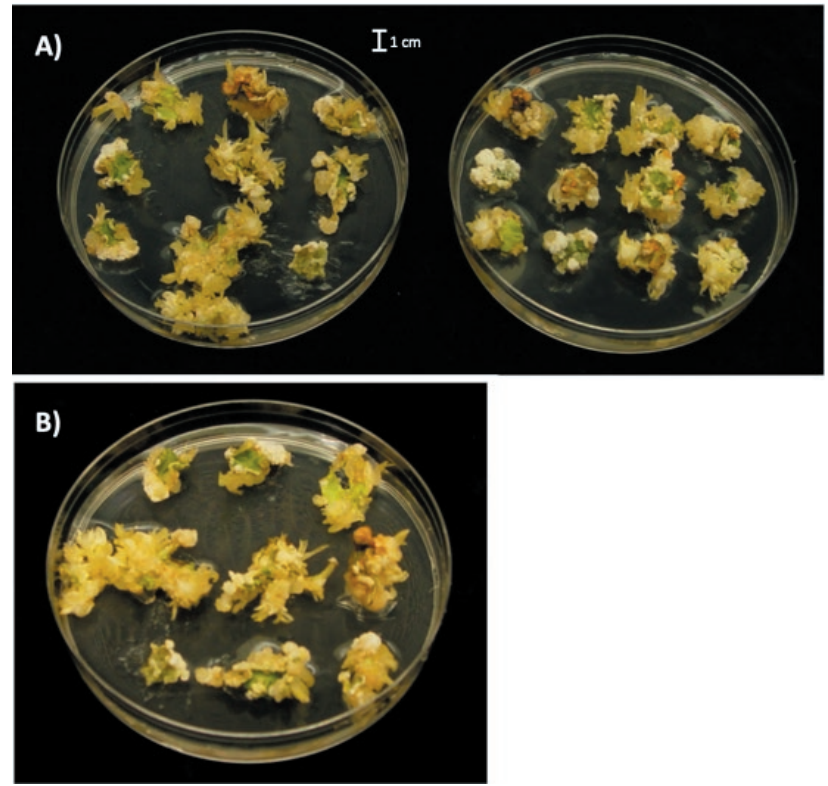

Figure 3. Regeneration of shoots after genetic transformation of leaf discs. On the right (a) treatment with the combination BA:NAA:TDZ (5:1:1) during co-cultivation; on the left (b) treatment with Agrobacterium "VIP" in co-transformation.

Table 2. Transformations of "Greensleaves" apple using construct Ino-IaaM. The construct, date, assigned number and description of the experiments are indicated. Percentage of regeneration and number of single or grouped shoots regenerated were measured. The letters on the side of the numbers in the same column for the same date experiment indicate significative differences calculated using the Duncan test $(\mathrm{P}=005)$.

\begin{tabular}{lcccc}
\hline $\begin{array}{l}\text { Experiment } \\
\mathrm{n} .\end{array}$ & Treatment & $\begin{array}{c}\% \\
\text { regeneration }\end{array}$ & $\begin{array}{c}\mathrm{N}^{\circ} \\
\text { of shoots }\end{array}$ & $\begin{array}{c}\mathrm{N}^{\circ} \text { of groups } \\
\text { of shoots }\end{array}$ \\
\hline 1 & Control & $32.73 \mathrm{~b}$ & $1.44 \mathrm{~b}$ & $1.33 \mathrm{~b}$ \\
2 & VIP & $17.67 \mathrm{a}$ & $0.84 \mathrm{a}$ & $0.33 \mathrm{a}$ \\
3 & Control & $26.13 \mathrm{~b}$ & $0.90 \mathrm{~b}$ & $0.93 \mathrm{~b}$ \\
4 & VIP & $7.73 \mathrm{a}$ & $0.40 \mathrm{a}$ & $0.25 \mathrm{a}$ \\
\hline
\end{tabular}

regeneration was obtained when co-transformation was not used (Figures 3, 4). All shoots transformed with one of the two ovule-specific constructs were transferred into a selective propagation medium containing 100 $\mathrm{mg} / \mathrm{L}$ kanamicin and $200 \mathrm{mg} / \mathrm{L}$ cefotaxime to select for transgenic shoots and avoid "escapes". Each single shoot was separated and grown separately, except in groups of indistinct shoots, where only one was chosen and propagated. The shoots with healthy growth were analyzed with a MUG assay to confirm the presence of the marker gene "GUS" in the constructs. Transgenic shoots were more fluorescent than control shoots (difference between Time 30 and Time 0; Table 3; Fig. 5).
A)

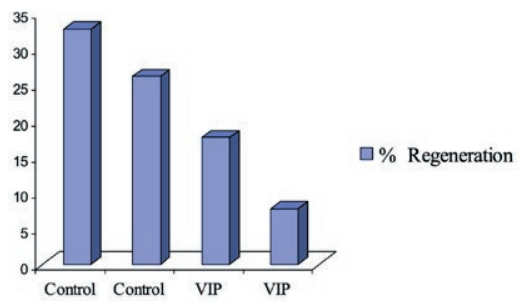

B)

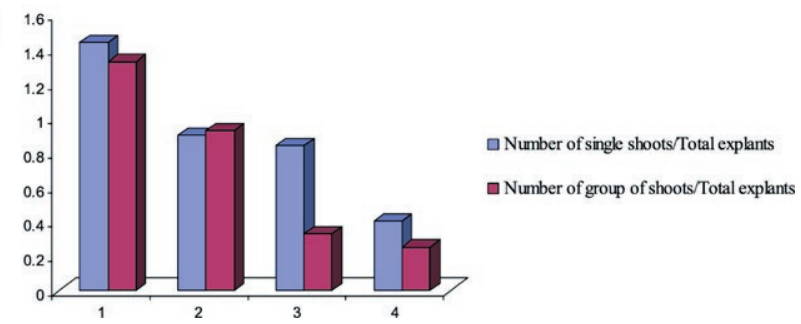

Figure 4. Genetic transformation of 'Greensleaves' apple leaf discs using the construct Ino-IaaM. The explants were cultivated in MS medium containing the combination BA:NAA:TDZ (ratio 5:1:1) either during co-cultivation or regeneration.

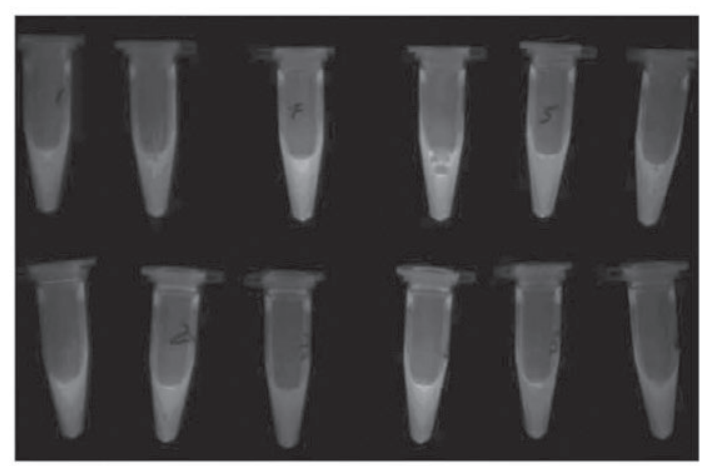

(a)

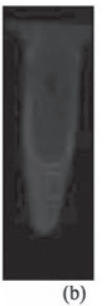

Figure 5. A) Transformation of 'Greensleaves' apple using a leaf disc infected by two Agrobacterium strains simultaneously: one containing the construct Ino-IaaM and the second with a "gene VIP" B) Transformation of 'Greensleaves' apple using a leaf disc infected by two Agrobacterium strains simultaneously: one containing the construct Ino-IaaM and the second with a "gene VIP".

\section{DISCUSSION}

Transformation of woody fruit species expressing marker genes has occurred in apple (James et al. 1993), Citrus (Vardi et al. 1990) and Vitis (Scorza et al. 1995). Perennial transgenic plants that express genes of agronomic interest have been obtained in Actinidia (Rugini et al.. 1991) and apple (Norelli et al. 1994). Usually, Agrobacterium-based methods were used because 
Table 3. Measurements of fluorescence of five single shoots regenerated from each transformation treatment and ten control Greensleaves cultured in vitro. The construct, treatment, $\mathrm{n}^{\circ}$ assigned to the shoot, presence of fluorescence at UV ("+ + " means fluorescence, "-"not fluorescence) and concentration at the beginning (Time 0) and end of the MUG assay (Time 30) were indicated.

\begin{tabular}{|c|c|c|c|c|c|}
\hline Construct & Treatment & $\mathrm{n}^{\circ}$ petri ( $\mathrm{n}^{\circ}$ plant) & UV fluorescence & $\begin{array}{c}\text { Total } \\
\text { Concentration }\end{array}$ & $\begin{array}{c}\text { Total } \\
\text { concentration }\end{array}$ \\
\hline \multirow[t]{15}{*}{ DefH9-IaaM } & 1 & $2(4)$ & + & 23700 & 159000 \\
\hline & 1 & $1(3)$ & + & 28200 & 463000 \\
\hline & 1 & $6(2)$ & + & 31300 & 260000 \\
\hline & 1 & $5(4)$ & + & 253000 & 241000 \\
\hline & 1 & $7(3)$ & + & 276000 & 245000 \\
\hline & 2 & $2(3)$ & + & 75500 & 102000 \\
\hline & 2 & $4(10)$ & + & 68600 & 542000 \\
\hline & 2 & $5(4)$ & + & 27100 & 451000 \\
\hline & 2 & $8(2)$ & + & 46700 & 532000 \\
\hline & 2 & $3(1)$ & + & 77600 & 746000 \\
\hline & 3 & $4(8)$ & + & 67200 & 442000 \\
\hline & 3 & $3(6)$ & + & 67500 & 578000 \\
\hline & 3 & $2(5)$ & + & 43500 & 876000 \\
\hline & 3 & $3(5)$ & + & 87100 & 783000 \\
\hline & 3 & $8(4)$ & + & 85000 & 903000 \\
\hline \multirow[t]{20}{*}{ Ino-IaaM } & 1 & $3(5)$ & + & 11000 & 613000 \\
\hline & 1 & $2(3)$ & + & 41700 & 403000 \\
\hline & 1 & $5(10)$ & + & 76500 & 338000 \\
\hline & 1 & $7(3)$ & + & 76500 & 338000 \\
\hline & 1 & $13(4)$ & + & 13300 & 141000 \\
\hline & 2 & $2(5)$ & + & 13300 & 141000 \\
\hline & 2 & $2(7)$ & + & 31300 & 1650000 \\
\hline & 2 & $11(5)$ & + & 12800 & 418000 \\
\hline & 2 & $2(4)$ & + & 58800 & 157000 \\
\hline & 2 & $4(6)$ & + & 55300 & 223000 \\
\hline & 3 & $9(4)$ & + & 12300 & 183000 \\
\hline & 3 & $11(7)$ & + & 82800 & 197000 \\
\hline & 3 & $3(4)$ & + & 30300 & 841000 \\
\hline & 3 & $15(6)$ & + & 31400 & 229000 \\
\hline & 3 & $2(3)$ & + & 56300 & 437000 \\
\hline & 4 & $7(11)$ & + & 68300 & 649000 \\
\hline & 4 & $12(2)$ & + & 63900 & 726000 \\
\hline & 4 & $13(4)$ & + & 92600 & 968000 \\
\hline & 4 & $4(5)$ & + & 74300 & 319000 \\
\hline & 4 & $15(3)$ & + & 28500 & 274000 \\
\hline \multirow[t]{10}{*}{ Control } & & 1 & - & 312 & 347 \\
\hline & & 2 & - & 367 & 386 \\
\hline & & 3 & - & 396 & 455 \\
\hline & & 4 & - & 474 & 606 \\
\hline & & 5 & - & 452 & 537 \\
\hline & & 6 & - & 573 & 612 \\
\hline & & 7 & - & 627 & 429 \\
\hline & & 8 & - & 391 & 621 \\
\hline & & 9 & - & 482 & 430 \\
\hline & & 10 & - & 619 & 329 \\
\hline
\end{tabular}


of their greater transformation efficiency and more stable integration of the transgene into the host plant genome. Agrobacterium strain LBA4404 has been used widely and the kanamycin-sensitive strain EHA105 was used to transform walnut (Mcgranahan et al. 1990) and apple (Dandekar et al. 2004). The virulence of Agrobacterium strains against different crops can vary. Different alleles of vir $\mathrm{G}$ genes can increase virulence (Ghorbel et al. 2001). The expression of vir genes is also stimulated by different environmental factors, like $\mathrm{pH}$, temperature and osmotic conditions. The length of in vitro cocultivation of explants with bacteria influences transformation efficiency, which generally increases with time. However, co-cultivation of more than three to four days can make it difficult to control Agrobacterium growth (Petri et al. 2004). The efficiency of transformation can be increased if the medium contains phenolic compounds like acetosyringone or osmoprotectants such as betaine phosphate and proline. These metabolites stimulate induction of the virulence genes (James et al. 1993).

Two gene constructs, Ino-IaaM and DefH9-IaaM, previously used to transform Micro-Tom tomato, were used to test different hormone combinations to improve a genetic transformation protocol for 'Greensleaves' apple. A secondary objective was to create transgenic plants that might be tested in the future for parthenocarpy, since this feature might counter the auto-incompatibility of many apple cultivars. In addition, Malus spp. are sensitive to adverse environmental conditions for pollination and/or fertilization. A parthenocarpic apple orchard would have several benefits. No pollination or fertilization would be needed for fruit set, making fruit set resistant to inclement weather, which would allow consistent production of high-quality fruit.

There are currently transformation protocols for many apple cultivars, such as Greensleaves (James et al. 1993), Delicious (Sriskanadarjah et al. 1994), Royal Gala (Yao et al. 1995) and Marshal McIntosh (Bolar et al. 1999). However, these protocols would benefit from more efficient regeneration of transgenic shoots. While a protocol for transformation of apple cv Greensleaves has been developed (James et al. 1993), the transformation rate is only one to three \% of the total explants. A recent and reliable procedure for grape transformation has been developed using meristematic bulk (MB tissue) made using mechanical and chemical treatments. $\mathrm{MB}$ tissue has a high regenerative competence and can be transformed efficiently by Agrobacterium (Xie et al.. 2016). This protocol should be tried in apple.

Our protocol used mature leaf discs. The developmental stage of the explant is an important factor influencing genetic transformation. Juvenile material regen- erated better than old material in Citrus (12 to $80 \%$ vs 6\%; Cervera et al. 1998). In apple, genetic transformation rates are < 3\% (Dandekar et al. 2004); in pear cultivars, $<1$ to $43 \%$ depending on genotype (Zhu and Welander, 2000); while in Prunus, protocols that regenerate transformed buds from $30 \%$ of explants were obtained almost thirty years ago (Mante et al. 1991).

Our protocol tested two hormones, BA (benzyl adenine) and NAA (naphthalene acetic acid) for their ability to stimulate regeneration of transgenic shoots. Our work was based on preliminary evidence that 'Greenleaves' leaf explants regenerated three to four times more shoots per explant with diphenyl urea thidiazuron (TDZ) combined with other medium changes, such as concentration of silver nitrate. The concentration of TDZ used is critical because high concentrations may cause "condensed" axillary shoots that do not elongate or proliferate in culture. In these experiments, a combination of $1 \mathrm{mg} / \mathrm{mL} \mathrm{TDZ,} 5 \mathrm{mg} / \mathrm{mL} \mathrm{BA}$ and $1 \mathrm{mg} / \mathrm{mL}$ NAA were used to regenerate transgenic shoots. Cotransformation with an Agrobacterium strain containing "VIP" genes did not increased the percentage of transgenic shoots regenerated. Using IBA instead of the combination BA:TDZ:NAA during co-cultivation increased the amount of callus without increasing regeneration of transgenic shoots.

Other factors that can affect regeneration were evaluated. These included the biological source of the explants (leaf age, maturity and position on the stem, explant orientation) or environmental conditions (nitrogen concentration, growth regulators, incubation time and temperature; Oliveira et al. 1996). Here, we used mature leaf discs. Young leaves are very useful as an explant source and morphogenesis occurred mainly at the cut edges of midribs, or in association with vascular tissues. Regeneration ability may be affected by stress induced by genetic transformation itself (Oliveira et al. 1996). A factor that greatly affects the regeneration capability is the amount, type and timing of the antibiotics used to kill Agrobacterium (Sain et al. 1994). Together with the gene of interest, other genes are transferred to allow selection of transformed cells. Among these, antibiotic resistance genes are common, such as the neomycin phosphotransferase gene (nptII) that confers resistance to aminoglycoside antibiotics (Miki and McHugh, 2004). Carbenicillin and kanamycin are used widely as selection antibiotics and can yield quite different results in different species. For example, in Citrus, pear, walnut or olive, $100 \mathrm{mg} / \mathrm{L}$ kanamycin is used for selection, but in Prunus, the concentrations are usually five to $10 \mathrm{mg} / \mathrm{L}$. In apple, alternate periods of selection and non-selection, or selection applied only on the regener- 
ated shoots, were used (James et al. 1993). Selection of transformed shoots is also complicated by the presence of escapes (non-transformed shoots) due to inactivation of antibiotics by transformed cells or by the persistance of Agrobacterium in the explants. Because of public concern with introducing antibiotic resistance genes into food, methods have been developed to eliminate them from the selection process (Zuo et al. 2002). For instance, a reporter gene such as Gus ( $\beta$-glucoronidase gene) can be used to evaluate transformation efficiency by visual selection. To avoid bacterial contamination, Gus genes that cannot be spliced out by the host cells were used. In Prunus, this method is still complicated by intrinsic GUS-like activity of the plants. The number of transformants obtained is usually underestimated by at least $25 \%$ when based on the expression of screenable marker genes (Oliveira et al. 1996). Kanamycin resistance is still a common strategy for selecting transgenic shoots, but the strong selection required to avoid escapes or chimeras reduces the number of cells that both received the DNA and regenerated buds. An innovative approach has improved transformation efficiencies tenfold over kanamycin selection in recalcitrant species. This method is based on giving transformants a metabolic advantage, rather than on killing non-transformed cells (Joersbo, 2001). It is hypothesized that necrosis produced by antibiotics in non-transformed tissues could inhibit regeneration from transformed adjacent tissues (Joersbo, 2001). Using regeneration-promoting genes, combined with hormone-free regeneration medium, could also substitute for traditional antibiotic marker genes. With no growth regulators, only transformed cells can regenerate, allowing simple screening for putative transformants without using a marker gene.

Much work is devoted to identifying regeneratingpromoting genes, presumably related to cytokinin synthesis, that enable the embryogenic or organogenic transition (Zuo et al. 2002). The Ipt gene, from Agrobacterium, must be used under the control of a inducible promoter, because constitutive over-expression of this gene can cause phenotypic growth disorder (Kunkel et al. 1999).

\section{CONCLUSIONS}

Explants transformed with either Ino-IaaM or DefH9-IaaM transgenes regenerated more shoots on combination of three hormones (BA:NAA:TDZ) than on IBA and co-transformation had no effect. In experiments using DefH9-IaaM, the percentage of regeneration for the hormone combination was significatively greater than for the other two treatments $(21.04 \%$ vs 8.95 and $4.42 \%$, respectively). The number of transgenic shoots was also greater with the hormone combination ( $1.52 \%$ vs 0.78 and $0.47 \%$, respectively). Experiments using Ino-IaaM confirmed these results. Co-transformation with Agrobacterium containing VIP genes was deleterious to production of regenerants, possibly due to a lower concentration of Agrobacterium containing the Ino-IaaM or DefH9-IaaM transgene during infection.

Most shoots regenerated in selection medium containing $100 \mathrm{mg} / \mathrm{L}$ kanamycin at were transgenics with significantly greater fluorescence in the MUG assay than untransformed, regenerated Greensleaves. This suggests that this concentration of kanamycin provided a good balance between selection of transgenic shoots and allowing reasonable regeneration efficiency.

\section{AUTHOR CONTRIBUTIONS}

MF and AMD designed and conceived the research work. MF performed the experimental work and statistical analysis. MF mainly wrote the article. AP and AMD reviewed and discussed results. All authors contributed significantly on the writing of the manuscript.

\section{REFERENCES}

Bolar J.P., Norelli J.L., Harman G.E., Brown S.K., Aldwinckle, H.S. 2001. Synergistic activity of endochitinase and exochitinase from Trichoderma atroviride (T-harzianum) against the pathogenic fungus (Venturia inaequalis) in transgenic apple plants. Transgenic Research, 10 (6): 533-543.

Bolar J.P., Norelli J.L., Wong K.W., Hayes C.K., Harman G.E., Aldwinckle H.S. 2000. Expression of endochitinase from Trichoderma harzianum in transgenic apple increases resistance to apple scab and reduces vigor. Phytopathology, 90 (1): 72-77.

Broothaerts W., Keulemans J., Van Nerum I. 2004. Selffertile apple resulting from S-RNase gene silencing. Plant Cell Reports, 22 (7): 497-501.

Cervera M., Pina J.A., Juraez J., Navarro L., Pena L. 1998. Agrobacterium-mediated transformation of citrus:factors affecting transformation and regeneration. Plant Cell Reports, 18 (3-4): 271-278.

Dandekar A.M., 1992. Transformation. In:Biotechnology of Perennal Fruit Crops. Hammerschlag FA Litz RE eds CAB International, 141-168.

Dandekar A.M., Teo G., Defilippi, B.G., Uratsu, S.L., Passey, A.J., Kader, A.A., Stow, J.R., Colgan R.J.,, James 
D.J. 2004. Effect of down-regulation of ethylene biosynthesis on fruit flavor complex in apple fruit. Transgenic Research, 13 (4): 373-384.

Dandekar A.M., McGranahan G.H., Vail P.V., Uratsu S.L., Leslie C.A., Tebbets J.S. 1998. High levels of expression of full-length cryIA(c) gene from Bacillus thuringiensis in transgenic somatic walnut embryos. Plant Science, 131 (2): 181-193.

Delbarre A., Muller P., Imhoff V., Barbierbrygoo H., Maurel C., Leblanc N., Perrotrechemann C., Guerin J. 1994. The RolB gene of Agrobacterium-rhyzogenes does not increase the axin sensitivity of tobacco protoplasts by modifying the intracellular auxin concentration. Plant Physiology, 105 (2): 563-569.

Donzella G., Spena A., Rotino G.L.. 2000. Transgenic parthenocarpic eggplants:superior germplasm for increased winter production. Molecular breeding, 6 (1): 79-86.

Faize M., Sourice S., Dupuis F., Parisi L., Gautier M.F., Chevreau E. 2004. Expression of wheat puroindoline- $b$ reduces scab susceptibility in transgenic apple (Malus $x$ domestica Borkh). Plant Science, 167 (2): 347-354.

Fitch M.M.M., Manshardt R.M., Gonsalves D., Slightom J.L. 1993. Transgenic papaya plants from agrobacterium-mediated transformation of somatic embryos. Plant Cell Reports, 12: 245-249.

Ghorbel R., La-Malfa S., Lopez M.M., Petit A., Navarro L., Pena L. 2001. Additional copies of virG from pTiBo542 provide a super-transformation ability to Agrobacterium tumefaciens in citrus. Physiological and Molecular Plant Pathology, 58 (3): 103-110.

Hidaka T., Omura M. 1993. Transformation of citrus protoplasts by electroporation. Journal of the Japanese Society for Horticultural Science, 62 (2): 371-376.

James D.J., Uratsu S., Cheng J.S., Negri P., Viss P., Dandekar A.M. 1993. Acetosyringone and osmoprotectants like betaine or praline synergistically enhance agrobacterium-mediated transformation of apple. Plant Cell Reports, 12 (10): 559-563.

Jia D., Fan L., Shen J., Qin S., Li F., Yuan Y. 2019. Genetic transformation of the astaxanthin biosynthetic genes bkt and crtR-B into apple tree to increase photooxidation resistance. Scientia Horticulturae, 3: 428-433.

Joersbo M. 2001. Advances in the selection of transgenic plants using non-antibiotic marker genes. Physiologia Plantarum, 11 (3): 269-272.

Kunkel T., Niu Q.W., Chan Y.S., Chua N.H. 1999. Inducible isopentenyl transferase as a high-efficiency marker for plant transformation. Nature Biotechnology 17 (9): 916-919.

Liu Q., Ingersoll J., Owens L., Salih S., Meng R., Hammerschalg F., 2001- Response of transgenic Royal Gala apple (Malus $x$ domestica Borkh) shoots carrying a modified cecropin MB39 gene, to Erwinia amylovora. Plant Cell Reports, 20 (4): 306-312.

Mante S., Morgens P.H., Scorza R., Cordts J.M., Callahan A.M. 1991. Agrobacterium-mediated transformation of plum (Prunus domestica l) hypocotil slices and regeneration of transgenic plants. Bio/Technology, 9: 853857.

Martinelli F., Uratsu S.L., Reagan R.L., Chen Y., Tricoli D., Fiehn O., Rocke D.M.., Gasser C.S., Dandekar A.M., 2009. Gene regulation in parthenocarpic tomato fruit. Journal of Experimental Botany, 60 (13): 3873-3890.

McGranahan G.H., Leslie C.A., Uratsu S.L., Dandekar A.M., 1990. Improved efficiency of the walnut somatic embryo gene-transfer system. Plant Cell Reports, 8 (9): 512-516.

Meister R.J., Williams L.A., Mona M.M., GallAgher T.L., Kraft E.A., Nelson C.G., Gasser C.S. 2004. Definition and interactions of a positive regulatory element of the Arabidopsis INNER NO OUTER promoter. The Plant Journal, 37: 426-438.

Miki B., McHugh S., 2004. Selectable marker genes in transgenic plants:applications, alternatives and biosafety. Journal of biotechnology, 107 (3): 193-232.

Nakamura Y., Sawada H., Kobayashi S., Nakajima I., Yoshikawa M. 1999. Expression of soybean beta1,3-endoglucanase cDNA and effect on disease tolerance in kiwifruit plants. Plant Cell Reports, 18 (7-8): 527-532.

Norelli J.L., Aldwinckle H.S., Destefanobeltran L., Jaynes J.M. 1994. Transgenic malling-26 apple expressing the attacin-E gene has increased resistance to Erwinia amylovora. Euphytica, 77 (1-2): 123-128.

Petri C., Alburquerque N., Garcia-Castillo S., Egea J., Burgos L. 2004. Factors affecting gene transfer efficiency to apricot leaves during early Agrobacterium-mediated transformation steps. Journal of Horticultural Science and Biotechnology, 79 (5): 704-712.

Puterka G.J., Bocchetti C., Dang P., Bell R.L., Sorza R. 2002. Pear transformed with a lytic peptide gene for disease control affects nontarget organism, pear psylla (Homoptera; Psyllidae). Journal of economic entomology, 95 (4): 797-802.

Oliveira M.M., Miguel C.M., Raquel M.H. 1996. Transformation studies in woody fruit species. Plant Tissue Culture and Biotechnology, 2: 76-92.

Rizzini F.M., Bonghi C., Chkaiban L., Martinelli F., Tonutti P. 2010. Effects of postaharvest partial dehydration and prolonged treatments with ethylene on transcript profiling in skins of wine grape berries. Acta horticulturae 877: 1099 -1104. 
Sain S.L., Oduro K.K., Furtek D.B. 1994. Genetic-transformation of co-cua leaf-cells using agrobacteriumtumefaciens. Plant Cell and Organ Culture, 37 (3): 243-251.

Sedira M., Holefors A., Welander M. 2001. Protocol for transformation of the apple rootstock Jork 9 with the rolB gene and its influence on rooting. Plant Cell Reports, 20 (6): 517-524.

Smigocki A.C., Hammerschlag F.A. 1991. Regeneration of plants from peach embryo cells infected with a shooty mutant strain of agrobacterium. Journal of the American society for Horticultural Science, 116 (6): 10921097.

Raman V., Anand A., Vasudevan B., Morsy R.M., Pant B.D., Lee H.-K, Tang Y., Mysore K.S. 2019. Overexpression of VIRE2-INTERACTING PROTEIN2 in Arabidopsis regulates genes involved in Agrobacteriummediated plant transformation and abiotic stresses. Scientific Reports, 9: 13503.

Rugini E., Pellegrineschi A., Mencuccini M., Mariotti D., 1991. Increase of rooting ability in the woody species kiwi (Actinidia deliciosa A Chev) by transformation with Agrobacterium rhizogenes rol genes. Plant Cell Reports, 10: 291-295.

Schuerman P.L., Dandekar A.M. 1993. Transformation of temperature woody crops-progress and potentials. Scientia horticulturae, 55 (1-2): 101-124.

Scorza R., Cordts J.M., Ramming D.W., Emershad R.L. 1995. Transformation of grape (Vitis vinifera L) zygotic-derived somatic embryos and regeneration of transgenic plants. Plant Cell Reports, 14 (9): 589-592.

Sriskandaraiah S., Mullins M.G., 1981. Micropropagation of Granny Smith apple-factors affecting root-formation in vitro. Journal of Horticultural Science, 56 (1): 71-76.

Sriskandarajah S., Goodwin P.B., Speirs J., 1994. Genetictransformation of the apple scion cultivar delicious via agrobacterium-tumefaciens. Plant Cell Tissue and Organ Culture 36 (3): 317-329.

Tosetti R., Martinelli F., Tonutti P., Barupal D.K. 2010. Metabolomics approach to studying minimally processed peach (Prunus persica) fruit. Acta Horticulturae 1017-1021.

Yao J.L., Cohen D., Atkinson R., Richardson K., Morris B. 1995. Regeneration of transgenic plants from the commercial apple cultivar Royal gala. Plant Cell Reports, 14 (7): 407-412.

Vardi A., Bleichman S., Aviv D. 1990. Genetic transformation of citrus protoplasts

and regeneration of transgenic plants. Plant Science, 69 (2): 199-206.

Xie X., Aguero C., Wang Y., Walker A. 2016. Genetic transformation of grape varieties and rootstocks via organogenesis. Plant Cell, Tissue and Organ Culture, 126: 541-552.

Welander, M., Pawlick, N., Holefors, A., Wilson, F. 1998. Genetic transformation of the apple rootstock M26 with the RolB gene and its influence on rooting. Journal of Plant Physiology, 153 (3-4): 371-380.

Zhu L.H., Welander M. 1999. Growth characteristics of apple cultivar Gravenstein plants grafted onto the transformed rootstock M26 with rolA and rolB genes under non-limiting nutrient conditions. Plant Science, 147 (1): 75-80.

Zuo J.R., Niu Q.W., Ikeda Y., Chua N.H. 2002. Markerfree transformation:increasing transformation frequency by the use of regeneration- promoting genes. Current opinion in biotechnology, 13 (2): 173-180. 